\title{
"MISSION IMPOSSIBLE": THE INTERMEDIARY ROLE OF THE DUTCH POLITICIAN AND JOURNALIST FRANS GOEDHART IN THE DUTCH- INDONESIAN CONFLICT, 1945-1947
}

\author{
Madelon de Keizer
}

\section{Introduction}

The sad story of the Netherlands' negative response to Indonesia's struggle for independence is only too well known. After the Japanese defeat in 1945, vehement resistance in the Dutch East Indies, two military actions against the Indonesian Republic, and recurrent international intervention were needed to induce the Dutch government finally to transfer sovereignty to its colony in December 1949.

The liquidation of the Dutch overseas empire in Southeast Asia was an extremely painful experience for the political parties at home. Ranking foremost among them was the Dutch Labor Party. Since the 1930s the social democrats had identified themselves with the general movement toward independence and decolonization. After 1945, however, their party was co-responsible for the ill-fated course of the Dutch-Indonesian conflict.

A major source for this essay was my interviews with Mr. Goedhart on October 9 and 29, and November 15, 1982 about his political role in the Indonesian situation. I am most grateful to Mrs. M.A.A.W. Goedhart-van Alebeek, who gave me permission to make use of the archive of her late husband, and I want to thank the head of the Second Department of the Algemeen Rijksarchief (ARA) in The Hague, Mr. E. van Laar, for his help during my visits to the ARA. My special thanks go to Mr. M. Baertl, a staff member of the ARA, who gave me ample advice and assistance. The unpublished Master's thesis, written by Jan Schenkman, "De Indonesië-reizen van Goedhart, alias Pieter 't Hoen. Een land in Revolutie. Bevindingen en vertolking" (University of Nijmegen, 1990), was very helpful to me, and I want to thank Prof. J. Bosmans at Nijmegen University for bringing this thesis to my notice. I am deeply in debt to Mr. Schenkman who gave me permission to make free use of the outcome of his research on Goedhart's travels to Indonesia in 1946, 1947, and 1952. My thanks also go to Dr. M. Campfens of the International Institute for Social History (IISG) in Amsterdam, who helped open the archives for my research as quickly as possible. Finally, I wish to thank Prof. Dr. H. Daalder, Dr. C. Touwen-Bouwsma, W. ten Have, D. Barnouw, M Baertl, J. Schenkman, Dr. L. Blussé, and Mrs. M.A.A.W. Goedhart-van Alebeek for their critical comments on an earlier draft of this article. 
The unexpected manner in which the Labor Party dealt with the Dutch postwar colonial legacy has been generally explained to date in terms of unfavorable political pressure from its conservative government partner. ${ }^{1}$ In the parliamentary elections of May 1946, both the Labor Party and the Roman Catholic Party were winners, but, as neither party got a majority, a coalition cabinet had to be formed. A more or less progressive social and economic political program of reconstruction and renewal was agreed upon, imperative for a country that was devastated and greatly impoverished after five years of German occupation. In order to enhance the emancipation of the Dutch workers in the projected welfare state, the Labor Party had to cooperate with a partner which harbored fundamentally different views about decolonization. Taking Dutch interests to heart, the leaders of the Catholic Party were not willing to allow any concessions to Indonesian nationalism at all, an opinion to which the other confessional parties and the liberals fully subscribed. Yet, it was this coalition government that had to deal with the aspirations of the Indonesian nationalists and the reality of the existence of the Indonesian Republic.

The political strains which caused the Labor Party to follow a highly moderate and, in the end, even anti-Republic policy have been the subject of much research elsewhere. ${ }^{2} \mathrm{By}$ emphasizing the party's problematic position almost exclusively in terms of coalition politics, internal party political necessities, and exigencies posed by Dutch public opinion, studies of the issue have tended, however, to overlook the specific character of socialist anticolonialist ideology as a possible component of socialist embarrassment in the period during which the Netherlands tried to retain its colony. Based fundamentally on the same Eurocentric and colonial discourse permeating the entire Western civilization at the time, socialist anticolonialism could not offer an alternative analysis of the Indonesian nationalist and social revolution and its dynamics. The misconceptions and irritations about to emerge from this apparent lack of socialist analytical tools turned out to mesh strikingly with priorities posed by the party's Catholic coalition partner and the need to conform to a public opinion that from 1945 onward was ardently anti-Republic.

The limitations of socialist anticolonialism are illustrated well by the dynamic decolonization strategy of the socialist journalist and politician Frans Goedhart. In this essay, I intend to bring into focus his specific political role as a middleman between the Netherlands and the Indonesian Republic during the first two years of the Dutch-Indonesian conflict. Although a member of the small but authoritative group of socialists who ardently opposed the Labor Party's colonial policy, Goedhart had a conception of the decolonization process which, inspired as it was by a "mission civilisatrice" in socialist disguise, did not in fact deviate basically from the party's anticolonialist standpoint. For that reason, Goedhart's

\footnotetext{
1 F. van Baardewijk, "De PvdA van het koninkrijk 1945-1947," in Het tweede jaarboek voor het democratisch socialisme (Amsterdam: De Arbeiderspers, 1980), pp. 164-212; J. Bank, "De PvdA en de Indonesische revolutie," in Socialisme en democratie 12 (1981): 585-93; J.Th.J. van den Berg, "Het miskende tijdvak: de eerste twintig jaar van de Partij van de Arbeid," in Het zevende jaarboek voor het democratisch socialisme (Amsterdam: De Arbeiderspers, 1986), pp. 14-42; Harry Poeze, "De Indonesische kwestie in 1945-1950. Sociaal-demokratie in de klem," in Nederland, links en de koude oorlog: breuken en bruggen, ed. Joost Divendal, Arnold Koper et al. (Amsterdam: De Populier, 1982), pp. 38-57.

2 Ibid. See also J. Bank, Katholieken en de Indonesische Revolutie (Dieren: De Bataafsche Leeuw, 1984) and L. Palmier, Indonesia and the Dutch (London: Oxford University Press, 1965). Of course, socialist commentators put forward this explanation with ardor during and after the crucial period. See, e.g., J. de Kadt, "'Rampspoed geboren.' Rondom de 20ste juli 1947," in J. de Kadt, De deftigheid in het gedrang. Een keuze uit zijn verspreide geschriften, ed. M.C. Brands, R. Havenaar and B.A.G.M. Tromp (Amsterdam: Van Oorschot, 1991), pp. 288-309; and J. de Kadt, De Indonesische tragedie. Het treurspel der gemiste kansen (Amsterdam: Van Oorschot, 1949).
} 
partly self-assumed mediatory mission in behalf of the Dutch Labor Party simply had to fail. His role as a middleman clearly displays the limits to socialist anticolonialism.

Although in most publications about this period of Dutch decolonization, reference is made to both Goedhart's criticism of the Labor Party's politics and his service as the party's delegate to the Indonesian socialist parties in the summer of 1947, a more balanced assessment of his remarkable political role can now been made thanks to the new archival material that has recently become accessible to scholarly research. ${ }^{3}$ In the following, I will first briefly survey the biographical background of this self-willed journalist and politician and appraise the nature of his political approach to the Dutch-Indonesian conflict. Subsequently, after an inquiry into the contents of his socialist anticolonialism, Goedhart's political achievements in the period 1945-1947 will be considered. By this biographical method I intend to enhance an understanding of the fundamental ambiguities of socialist anticolonialism.

\section{A Middleman}

In the crisis-ridden decade preceding the outbreak of the Second World War, Frans Goedhart (1904-1990) had to struggle hard to earn a decent living as a journalist. In the early 1930s, he was employed by the Dutch Communist daily, the Tribune. He turned out to be not only a socially and politically engaged reporter but a devoted member of the party as well. After a couple of years, however, he could no longer support the party's policy. Its slavish obedience to Moscow's directions seemed to Goedhart harmful to the antifascist struggle. A short period of intraparty opposition followed, and in 1934 he was finally expelled. Briefly active in one of the other small radical leftist parties flourishing in the Netherlands in the mid-1930s, he gradually became sympathetic toward social democracy, although never joining the ranks of the Dutch Social Democratic Workers' Party (SDAP).

At the end of the decade, Goedhart was a freelance journalist writing for a Belgian socialist daily. When the Germans invaded the Netherlands in May 1940, he did not flee the country. Three months later, he brought out the forerunner of the resistance paper Het Parool, to be published from 1941 until the liberation. In 1945, as a logical outcome of his prewar and wartime political and journalistic career, Goedhart sought to combine both careers once again, inseparable as they were in his opinion. In the first postwar months, he was the deputy editor-in-chief of the daily Het Parool. From August 1945 on, he headed the foreign policy section of this independent socialist paper, which, under one of Goedhart's most capable wartime co-editors, was soon held in high regard. At the same time, his prominence as a resistance hero brought Goedhart to the temporary Parliament that functioned until the first postwar elections, held in May 1946. Although a prominent member of the new Dutch Labor Party, he was not chosen for the new Parliament. In September 1946, however, when the new government sent the Laborite W. Schermerhorn to Batavia as

\footnotetext{
${ }^{3}$ In 1991 Goedhart's personal archive was transferred to the Algemeen Rijksarchief (ARA) in The Hague. Reference to Goedhart's political role in the Dutch-Indonesian conflict has been made among others by Van Baardewijk, "De PvdA van het koninkrijk 1945-1947"; Bank, Katholieken en de Indonesische Reoolutie; Poeze, "De Indonesische kwestie in 1945-1950"; M.P. van der Vusse, "De Partij van de Arbeid, Nederland en de Indonesische Revolutie," Master's thesis, RUU, 1984; S.L. van der Wal, P.J. Drooglever, and M.J.B. Schouten, Officiële bescheiden betreffende de Nederlands-Indonesische betrekkingen 1945-1950, vols. V, VI, and IX. (The Hague: Staatsuitgeverij, 1975, 1976, and 1981).
} 
chairman of the Commissie-Generaal, the Commission General that had to negotiate with the Indonesian Republic, Goedhart replaced him in the Second Chamber.4

The Dutch Labor Party was founded in February 1946, replacing the prewar Social Democratic Workers' Party. The new Partij van de Arbeid was, in composition, an amalgamation of non-Communist progressives. Although social democrats formed the majority of the new party's members, a number of Catholics and Protestants joined it as well. This was a new phenomenon in Dutch politics. In prewar times, due to the strong religious division of Dutch society, diverse population groups had founded their own religion-based political parties and cultural and educational organizations. ${ }^{5}$ The new Labor Party, now trying to encompass not only the workers but middle-class people as well, aspired to cut through the traditional lines of class and religion by offering a non-Marxist progressive political program. The diverse membership of the new Labor Party after February 1946 clearly influenced the party's outlook. In order to accommodate the different political viewpoints and to keep the party together, the leadership took pains to avoid extreme positions. This strategy motivated its attitude toward Indonesian nationalism as well. 6

Goedhart had been strongly in favor of the founding of the new Labor Party. Before the war he had shared the more generally held view that Dutch government and society were completely corrupted by the economic and political crisis. In his opinion, the old, rigid, and ineffective government needed reorganization and rejuvenation. A new Labor Party should take the lead in the ensuing radical socialist reconstruction of government and society. During the war these ideas were ardently put forward in Het Parool. At the founding congress of the Labor Party, Goedhart spoke on behalf of a group of formerly independent socialists who had joined the new party and told his audience that the new party had to follow a radical socialist course. Pivotal in its policies should be the reorganization of the colonial relationship between the Netherlands and the Dutch East Indies.

In the following years, Goedhart took it upon himself to become a middleman between the Netherlands and the Indonesian nationalists. In his opinion, the controversy needed to be brought to an end as soon as possible, not only for the benefit of the latter but for that of the Dutch as well. He attempted to bridge the gap between the two struggling parties and to provide highly valuable informal means of access by which the opponents could try to obtain their ends. ${ }^{8}$ With that aim in mind, he was quick to exploit his position as politician and journalist. Due to his unique status as the founder of Het Parool, he enjoyed nearly complete freedom to inspire his readers with more understanding of what was at stake in Indonesia. In Parliament, the Indonesian national revolution found in him one of its most sympathetic

\footnotetext{
4 The Dutch national legislature is called the States General. It is a bicameral legislative body. The Second Chamber is the lower house. It consisted at that time of 100 members. The First Chamber is the upper house, and had a membership of 50 . The Second Chamber is directly elected; the First Chamber is elected indirectly via the provincial legislatures.

5 For this characteristic of Dutch political life, see A. Lijphart, The Politics of Accommodation: Pluralism and Democracy in the Netherlands (Berkeley: University of California Press, 1975).

6 J. Bank, "De PvdA en de Indonesische revolutie," p. 585.

${ }^{7}$ M. de Keizer, "'De Partij van de Arbeid. Een Parool-ideaal wordt werkelijkheid': Het Parool en de Partij van de Arbeid," in Het zesde jaarboek voor het democratisch socialisme, ed. J. Bank, P. Kalma, M. Ros, and B. Tromp (Amsterdam: De Arbeiderspers, 1985), p. 100.

${ }^{8}$ Cf. Schenkman, "De Indonesië-reizen van Goedhart," p. 14-15. I derive the description of the middleman's activities from Audrey R. Kahin, "Brokers and Middlemen in Indonesian History: a Review," p. 137, in Indonesia 36 (October 1983): 135-42. To be effective, she writes, the middleman must also be involved with and central to the process of interaction. This, too, was the case with Goedhart's mediating role.
} 
and capable spokesmen. In Indonesia, nationalists held him in high esteem because of the balanced view he had presented of the future of the colony in Het Parool during the war and because of the positive analyses of the Indonesian revolution that he published after liberation.

Goedhart's independent socialist viewpoints and the outspoken way in which he usually delivered his opinion were not well received by everyone in the party. The party leadership loathed the individualism of this famous former resistance worker who could freely publish his opinions in a socialist daily that competed with the party's own paper. But at the same time it respected Goedhart's loyal nonconformity, which facilitated his mediating activity and served the leadership's objective of keeping the party together and securing its position in government. ${ }^{9}$ In allowing Goedhart to play a minor role in its Indonesian policy, the party leaders successfully accommodated those members who severely criticized the way they and the Laborite ministers in the cabinet were dealing with the Indonesian nationalists. Goedhart, on the other hand, employed this special position not only to the benefit of the Indonesian nationalist cause as he perceived it, but also to exert a radicalizing influence on the party leadership and its policies in general. In his opinion, the Labor Party was fundamentally failing in its purpose of radically renewing government and society after the war.

In June 1947, the chairman of the Labor Party sent Goedhart to the Indonesian Republic in a last attempt to induce the Indonesian social democratic sister organizations to a more accommodating political course. By that time, the Labor Party's complicity in the launching of a military action against the Indonesian Republic appeared unavoidable. For Goedhart grasping the chance to be an agent of history, this mission turned out to be a climactic experience in the policy of socialist decolonization.

\section{Goedhart's Socialist Anticolonialism}

Goedhart's view on the future of the Dutch East Indies combined elements of the social democratic anticolonial program of the 1930s, vaguely tainted by contemporary left-wing socialist viewpoints on the matter, with a highly nonlegalistic, nonconformist response to the Indonesian reality of 1945 . To help the Indonesian people gain their freedom was, according to him, one of the tasks the radical socialist Resistance had pledged to fulfill.

The colonial program of the Social Democratic Workers' Party dated from 1932. It had been formulated after a serious party crisis that had its origin in the party left-wing's opposition to the general reformist party line taking shape in the second half of the $1920 \mathrm{~s}$. The colonial question became an issue for the party because of the unrest in the Dutch East Indies at the time. "Indonesia, free from Holland now!" was the slogan of the opposition, that solicited the solidarity of the revolutionary socialist movements in the colonies as allies in the struggle against capitalism. At the party's Colonial Congress of 1930, the principles of its future colonial program were debated. In response to left-wing pressure, the statement that social democracy unconditionally recognized the right of national independence replaced support for limited national independence. In 1932, however, the left-wing split from the party. No longer harassed by radical anticolonial slogans, the party congress later that year unanimously approved a new colonial program stating that the eventual independence of Indonesia had to be advanced by evolutionary and peaceful decolonization. The party's

\footnotetext{
${ }^{9}$ All cabinets in the Netherlands have been coalition cabinets, necessitated by the Dutch multiparty system. Until 1958, they all had a Catholic-socialist coalition as their main foundation. The Catholic Party and the Labor Party each controlled about a third of the seats in the States General.
} 
new economic program of 1935 contained proposals for reforming the economic structure of the Dutch East Indies to meet the colony's own needs. ${ }^{10}$

Despite the fact that it now recognized the colony's right to independence, the social democratic political and economic program of the 1930s basically elaborated viewpoints held since the turn of the century embodied in the so-called Ethical Policy or "mission civilisatrice." Although the abortive Communist revolts of 1926-1927 in the Dutch East Indies had terminated this policy, elements of the strategy remained in the social democratic colonial program of 1932-35,11 which strongly focused on improving the colony's economic infrastructure. Once the regional economy was immune to world exploitation and a nonCommunist nationalist movement able to support itself, Indonesia would be, according to the social democratic scenario, ready to be politically independent as well. The program shrank from setting a timetable for abolishing metropolitan dominance, as it was realized that this political strategy for the time being served the economic interests of the crisisridden metropolitan working class well. This Realpolitik clearly illustrates the interdependency of the lofty social democratic decolonization ideals and the earthly needs of the Dutch working classes.

Moreover, the social democrats were well aware of the fundamental disagreements between themselves and the colonial nationalists:

The Dutch social democrats seek an alternative productive mode and oppose capitalism because it is capitalism. The nationalists oppose the same enemy but with an entirely different viewpoint. For them the enemy represents the national oppressor. Both thus stand on common territory against a common enemy, but each has its own goal. ${ }^{12}$

This statement by one of the party's spokesmen on the Colonial Congress, encapsulated the future socialist anticolonialist dilemmas. More explicitly, the socialists claimed to support the nationalist struggle with those means which they themselves considered most effective: "We have our own vision." 13

Although during World War II the colonial position of the Netherlands had been subject to much debate among the Dutch both in and outside the Resistance, and in the exile government in London as well, no essentially new viewpoints on the matter emerged. The discussion about the future status of the Dutch East Indies was mostly inspired by Queen Wilhelmina's address on December 7,1942. Prompted by the growing resistance to colonialism by the United States, the Netherlands' strong ally, she promised to hold a round table

\footnotetext{
${ }^{10}$ E. Hansen, "The Dutch East Indies and the Reorientation of Dutch Social Democracy, 1939-1940," in Indonesia 23 (April 1977): 59-85; P. van Tuyl, "Koloniale politiek in crisistijd; de SDAP en Indonesië, 1930-1935," in Het zevende jaarboek voor het democratisch socialisme (Amsterdam: De Arbeiderspers, 1986), pp. 44-73.

11 Van Tuyl, "Koloniale Politiek," p. 70, disputes the viewpoint that the Social Democratic Worker's Party's program might be considered as a continuation of elements of the Ethical Policy, as asserted, among others, by Bank, "De PvdA en de Indonesische revolutie," and H.F. Cohen, Om de vernieuwing van het socialisme. De politieke oriëntatie van de Nederlandse sociaal-democratie 1919-1930 (Leiden: Universitaire Pers Leiden, 1974), p. 43. About the Ethical Policy, see E. B. Locher-Scholten, Ethiek in fragmenten. Vijf studies over koloniaal denken en doen van Nederlanders in de Indonesische Archipel 1877-1942 (Utrecht: Hes Uitgevers, 1981); and R. van Niel, The Emergence of the Modern Indonesian Elite (The Hague: Nijhoff, 1970).

12 As cited in Hansen, "The Dutch East Indies," p. 74.

${ }^{13}$ Ibid.
} 
conference after the war about the colony's future. ${ }^{14}$ The underground social democratic party's "colonial" commission met again in 1944 and decided in favor of continuing the relationship with Indonesia, although eventually as a sovereign and equal partner in the Kingdom of the Netherlands, thereby not transgressing the framework of the December 7, 1942 , speech. ${ }^{15}$

No new positions were taken in the program that the new Labor Party accepted in 1946. The party leadership, deeply shocked by the declaration of independence by Sukarno and Hatta in August 1945, and the Netherlands' gloomy economic situation, decided after some discussion in favor of an enduring relationship with an eventually self-governing Indonesia, instead of a future Commonwealth that Indonesia was free to join or not. Already in this embryonic stage, the projected Labor Party's leadership had to consider the less progressive standpoints of some of the prominent, but originally not social democratic, future partners within the new socialist party who were against independence for Indonesia at all. ${ }^{16}$

Although highly critical of the Netherlands' prewar rule over the Dutch East Indies, Goedhart had, during the war, upheld the view in Het Parool that maintaining the political, cultural, and economic bonds with Indonesia in the future would be to the benefit of both Indonesia and the Netherlands. Indonesia should remain within the constitutional set-up of the Kingdom of the Netherlands, eventually as a self-governing country. ${ }^{17}$ The point of view of Goedhart and Het Parool was basically congruent with that of the socialists during the war. In the fall of 1945, however, differences in mentality and approach arose between a leftist group in the party, which included Goedhart and the publicists Jacques de Kadt and Sal Tas, and the party leadership. De Kadt and Tas had both left the Social Democratic Workers' Party in 1932 in protest against its reformist position. Like Goedhart, they had moved toward social democracy after the mid-1930s. After the war, Tas became, again like Goedhart, a member of the party during its transitional phase into the new Labor Party. De Kadt, who had been in the Dutch East Indies during the war, returned to the Netherlands in March 1946, and immediately joined the new party. Only in 1948 did he get a seat in Parliament. De Kadt and Tas were both employed by Het Parool, which from 1945 began to express the group's opposition to the colonial policy of the Labor Party and the Dutch government.

Goedhart's ideas about the future of Indonesia changed almost immediately after Sukarno and Hatta declared Indonesia independent. His opinions were strongly influenced by the views De Kadt published as a correspondent of Het Parool. De Kadt lived at the time in Bandung, where he helped the Dutch left-wing socialist D.M.G. Koch edit the periodical Kritiek en Opbouw (Criticism and Construction). He greatly admired the social democrat Sjahrir, whom he had known since 1942. After the Japanese capitulation, De Kadt even aspired for a while to become Sjahrir's political adviser. Once he became prime minister, Sjahrir arranged that De Kadt could go safely to Batavia to start writing for Het Parool. At the same time, De Kadt started to publish articles in a public relations bulletin of the Repub-

\footnotetext{
14 C. Fasseur, "Een wissel op de toekomst: de rede van Koningin Wilhelmina op 6/7 december 1942," in Between People and Statistics. Essays on Modern Indonesian History: presented to P. Creutzberg, ed. F. van Anrooij et al. (The Hague: Martinus Nijhoff, 1979), pp. 267-80.

15 Van Baardewijk, "De PvdA van het koninkrijk 1945-1947," pp. $166-69$.

16 Ibid., pp. 175-80.

${ }^{17}$ M. de Keizer, Het Parool 1940-1945. Verzetsblad in Oorlogstijd (Amsterdam: Otto Cramwinckel, 1991), pp. 31317.
} 
lic. He had ample opportunity to become well acquainted with both the Dutch government officials in Batavia and the Indonesian nationalists. 18

On the whole, De Kadt took a fairly realistic position. Before the war, he had rejected colonialism, which he viewed as the ultimate form of capitalistic exploitation. He proposed in 1945 that the Netherlands, because of the attitude of the Western allies, should encourage the founding of an independent and democratic Indonesia. All that the Netherlands could hope for was some kind of alliance with its former colony. Holland should realize that it was a small country that had to consider the wishes of its allies, if only because at the time British troops were responsible for keeping law and order on Java. ${ }^{19}$ De Kadt never tired of pointing out the reasonableness and moderation of Sjahrir and his political friends. He argued that only Sjahrir would be capable of ending the chaotic situation in the fall of 1945, the Bersiap period, in which Indonesian revolutionaries tried to speed up the dynamics of the Indonesian revolution by robberies and murders. By leaving Sukarno out of his political analyses of the Republic's situation, De Kadt attempted to counter Dutch accusations that the Republic was a Japanese creation, governed by former collaborators with the Japanese, and therefore unacceptable as a partner in negotiations. De Kadt described Sjahrir's position during the Japanese occupation of the Dutch colony as analogous to the Dutch resistance. Yet he considered Sukarno not a collaborator but a fanatic and idle egoist, striving after domination. Hatta he assigned to a position between collaboration and resistance, who, forced as a well-known Indonesian nationalist to cooperate with the Japanese, had at the same time employed all his skills in the preparation of Indonesia's independence. ${ }^{20}$

Goedhart presented De Kadt's views to the temporary Parliament. In January 1946, in the parliamentary debate about the government's policy, he grasped the opportunity to speak about Indonesian affairs. By that time, Holland was deeply shocked by the gruesome deeds of the Indonesian pemuda (youth) during the past Bersiap period. Although Goedhart accused these young revolutionary extremists of being fascists, murderers, and robbers, he nevertheless marked the Dutch as the real culprits responsible for the chaos in Indonesia. He displayed a realism that echoed that of De Kadt: "Whoever has the power and whoever is a rebel is defined by power relations and at present these are not very favorable for us. We should act according to the consequences." The Dutch government had to understand that the current balance of power was against colonial rule and that colonialism and democracy could not go together. In order to retain Indonesia, he concluded, paradoxically, political ties with the country had to be cut. Thereafter, the Netherlands could profit economically from its relations with its former colony which would be in urgent need of the experience and capability of the Dutch to exploit its resources. For that reason military action against the Indonesian Republic, aimed at forcing it into a union with the Netherlands, should never be allowed. ${ }^{21}$ Goedhart clearly felt that a shrewd appeal to Dutch economic self-interest would be more convincing than arguments based on socialist anticolonialism, realism in international relations, or emotional sympathy with a people fighting for its freedom.

\footnotetext{
$18 \mathrm{R}$. Havenaar, De tocht naar het onbekende. Het politieke denken van Jacques de Kadt (Amsterdam: Van Oorschot, 1990), p. 159 and pp. 160-61; J. de Kadt, Jaren die dubbel telden. Politieke herinneringen (Amsterdam: Van Oorschot, 1978), pp. 146-50.

19 J. de Kadt, De Indonesische tragedie, pp. 79-80; and Havenaar, De tocht naar het onbekende, p. 157.

${ }^{20}$ J. de Kadt, "Open brief aan minister Logemann," in J. de Kadt, ed. M.C. Brands et al., pp. 274-87.

21 F.J. Coedhart in the Second Chamber, January 15, 1946. Handelingen der Voorlopige Staten-Generaal, Tweede Kamer, 1945-1946, Verslag. (The Hague: Staatsuitgeverij, 1946), pp. 273-74.
} 
In the coming months Goedhart did his utmost to confront the overwhelming antiRepublican mood in the Netherlands by pointing out, time and again, that the Indonesians were not as anti-Dutch as they were alleged to be; that the nationalist movement and the Republic were not Japanese creations; nor was the situation on Java as bad as described in the heavily biased Dutch press. From January 1946, as a result of British mediation, the highest Dutch official in Batavia, Lieutenant Governor General H.J. van Mook, was working on an agreement with the nationalists. The prospects became so promising that in the latter half of April further talks took place with the Netherlands' government at Hoge Veluwe, near Arnhem. The government was, however, not willing to recognize the de jure sovereignty of the Republic over Java, nor did it agree with the Republic about its status in the interim period until sovereignty was transferred to Indonesia. It was clear, moreover, that the Dutch Parliament would never accept the proposals drafted in Batavia. In view of the coming Dutch elections in May, the government was unwilling to reach any agreement, and, consequently, the talks failed.22

A few weeks after the Hoge Veluwe talks and just before the elections were to be held, Parliament debated the report of the parliamentary commission that had been sent to Indonesia to judge the situation. In these debates Goedhart strongly condemned the report. In his opinion, the commission had gathered evidence only from the high colonial administration and the colonial establishment, who felt doomed to lose their former power and privileges and were thus resentful and bitter. It did not contribute in the least to the reconciliation of the Dutch with the Indonesian nationalists, nor was it a confirmation of the policy that had led to the ill-fated negotiations with the Republic at Hoge Veluwe. It was, on the contrary, a final attempt to obstruct any agreement at all. ${ }^{23}$

With this speech, Goedhart's first term in Parliament ended. The elections that month did not bring him back as a member of the new, first postwar Parliament. So he seized the opportunity to see for himself what the situation in Indonesia really was, and on June 15, 1946, he took the airplane to Batavia. His intention was not only to speak with Dutch officials and members of the colonial establishment, as the parliamentary commission had apparently done, but to consult representatives of all political, social, and economic groups in the Dutch East Indies and, particularly, to visit the Indonesian Republic. In this phase of the conflict, he considered it crucial to refute the contents of the parliamentary report of May 1946. His aim was to redress the negative public opinion about the Indonesian nationalists. ${ }^{24}$ Het Parool sent him as the paper's special correspondent.

\section{The First Dutch Journalist in Revolutionary Yogyakarta}

Goedhart stayed nearly eight weeks on this his first visit to the country. Shortly after his arrival on June 15, he met Sjahrir, who had remained in Batavia while Sukarno and his ministers had gone to Yogyakarta. A week later, Goedhart informed his fellow party member Schermerhorn, whom he held in high esteem because of his role in the Resistance and his earlier moderate political stance, that Sjahrir was willing to resume negotiations. Republican Prime Minister Sjahrir proposed holding a conference in Cairo, because, after the failure of the one at Hoge Veluwe, Holland no longer seemed a suitable place. A month

\footnotetext{
22 J. van Goor, Indië/Indonesië. Van kolonie tot natie (Utrecht: Hes Uitgevers, 1987), p. 100.

${ }^{23}$ F. J. Goedhart in the Second Chamber, May 6, 1946. Handelingen der Staten-Generaal, p. 725.

24 F. J. Goedhart to A. Sweers, June 6, 1946. ARA II, arch. Goedhart, corr. Indonesië.
} 
later, Schermerhorn wrote Goedhart that he certainly approved of the idea, but no steps were taken to pursue it. ${ }^{25}$

From Batavia, Goedhart went to Malino, a hill station near Makassar in the Celebes, to attend the conference of representatives of East Indonesia. The conference, orchestrated by the Dutch, convened on July 16. After the isolation caused by the Japanese occupation, it offered the first opportunity to the participants to get acquainted with each other. Carefully selected by the Dutch, they appeared to favor Van Mook's plan for a future federal structure of Indonesia, which was proposed by him in part as a means to dilute the Republic's strength in an eventual independent Indonesia.

After attending the Malino conference, Goedhart visited Bali and traveled through Java. On August 17, he was welcomed as a special guest of the Indonesian Republic in Yogyakarta, the Republic's capital, to participate in the festivities commemorating the first anniversary of independence. Although he saw Sukarno occasionally, he was apparently not allowed to interview him. But he did speak with Hatta, Subandrio, Setiadjit, Sutomo, Darmasetiawan, and many other well-known nationalists during his fourteen-day sojourn in the Republic. ${ }^{26}$ With the prominent Republican journalist Rosihan Anwar he rode on a truck through Yogyakarta, while both stayed in the same hotel, the Merdeka. ${ }^{27}$ Back in Batavia, Goedhart had several talks with Van Mook. ${ }^{28}$ On August 13, he addressed the Dutch social democrats of the Progressive Group, which was convening in the Loge building in Batavia. On his journeys, he also met with Dutch planters and industrialists. In short, he tried to see and interview as many spokesmen or representatives of the political, social, and economic life of Indonesia as possible.

From July 19 onward, Goedhart published about nine articles in Het Parool about his experiences. Regarding his journalism as part of his political agenda, he was well aware of the potential impact of his articles. So he described the dynamics of the political and social revolution in Indonesia and the party struggle in the Republic in simple terms, stressing more the similarities than the differences in political ideas between the Dutch and the Indonesian nationalists. He defended Sjahrir's "diplomasi" course and blamed the conservative colonial establishment in Batavia for the misunderstandings that contributed so strongly to its bad relationship with the Indonesian Republic. He wrote approvingly about Van Mook's federalist policy, citing the conference at Malino as a shining example of how "white and brown could go together." On August 19, he reported that the new Dutch prime minister's first statement, together with the ideas that the new minister of Overseas Territories expressed in an interview shortly thereafter, had been a great disappointment to the Indonesian nationalists. He was apparently appealing to the socialist ministers not to give in to the conservatives in the new Catholic-socialist coalition cabinet that had been installed earlier that month. ${ }^{29}$

\footnotetext{
${ }^{25}$ F. J. Goedhart to W. Schermerhorn, June 24, 1946; W. Schermerhorn to F.J. Goedhart, July 22, 1946. Ibid.

26 See Goedhart's articles in this period and his booklet Terug uit Djokja (January 1947). Also F.J. Goedhart to Anak Agung gde Agung, March 22, 1947; and F.J. Goedhart to A. Budiardjo, November 8, 1946. ARA II, arch. Goedhart, corr. Indonesië.

${ }^{27}$ F. J. Goedhart to A. Budiardjo, November 8, 1946. ARA II, arch. Goedhart, corr. Indonesië.

${ }^{28}$ F. J. Goedhart to H.J. van Mook, September 18, 1946. Ibid. They conferred with each other also about the founding of a progressive paper in Batavia.

${ }^{29}$ See Het Parool, July 19, 1946 ("Sjahrirs' Internal Problems" [transl.]; July 20, 1946 ("The Purge of the Indonesian Opposition to Sjahrir" [transl.]); July 26, 1946 ("The Colonial Establishment in Indonesia" [transl.], August 9, 1946 ("The Great Lesson of Malino" [transl.]).
} 
In January 1947, nearly five months after his return to the Netherlands, Goedhart published a booklet about his Indonesian journey, Terug uit Djokja (Back from Yogyakarta). The title and the design of its cover were strongly inspired by André Gide's Retour de l'U.R.S.S., published after his visit to the Soviet Union in 1936. In this book Gide had shown great moral courage by publicly repudiating his former belief in communism as a means for combatting human alienation, which was the major theme of his literary works. Goedhart's rather obvious reference to Gide's book must have been deliberately inserted to alert the well-educated reader. ${ }^{30}$ Far from repudiating the Indonesian Republic, however, his book contained a highly positive account of the Indonesian Republic, systematically counterbalancing Dutch prejudices and misunderstandings.

Terug uit Djokja was written in order to redress the growing Dutch alienation from the nationalists in Indonesia after the failure of the Hoge Veluwe talks. To reach a solution of the conflict, an atmosphere of mutual trust between the two opponents had to be created. To that end, he stressed the positive aspects of the Indonesian struggle for independence. Goedhart argued, in short, that in the Republic three pivotal developments had taken place, all well worth being considered by the Dutch. First, it should be noted that Sjahrir, Hatta, and Sjarifuddin pursued a constructive policy that aimed at ending the excesses of revolutionary violence. Second, it should be realized that Sukarno's popularity made him a politician whose signature could not be omitted from any eventual agreement with the Dutch. And finally, the Dutch had to understand that their policy toward a self-governing Indonesia, encompassed in a lasting confederation with the Netherlands (in "Koninkrijksverband"), was highly unrealistic in view of the Republic's deep distrust of Dutch intentions. ${ }^{31}$ Goedhart had in fact already reached this conclusion before his journey to Yogyakarta.

Goedhart's travels through Indonesia and the publication of his booklet evidently won him much goodwill. Among the nationalists, he was from now on known as "toean baik hati" ("the man with a good heart," the literal translation of Goedhart's name). 32 Subandrio, whom he had met as an offical of the Republic's Department of Public Information, credited him with having brought about a whole mental revolution in Batavia. The Dutch finally seemed to understand that the Indonesian Republic could no longer be ignored. ${ }^{33}$ Goedhart received a letter from a Dutch woman in Batavia who wished him luck in fulfilling his cultural task of renewing and strengthening the bonds between the democratic part of the Netherlands and awakened Indonesia. Terug uit Djokja strongly compensated for all the bad

\footnotetext{
30 Goedhart finished the manuscript in October 1946. Only in January 1947 did he know the title. Terug uit Djokja was not an aggressive title but rather neutral, although not "pointless," he wrote to his editor. F.J. Goedhart to A.J. Noordam, January 13, 1947. ARA II, arch. Goedhart, corr. Indonesië.

31 W.A. van Goudoever, chief of the Department of Political Reporting of the Dutch Information Service in Batavia, with whom Goedhart had had long conversations, sent a report of Goedhart's impressions to the government. Goedhart received a copy of this report as well. W. A. van Goudoever to F. J. Goedhart, September 2, 1946. ARA, arch. Goedhart, corr. Indonesië.

32 R. Alwi to F. J. Goedhart, January 14, 1947. Ibid. The Republican journalist Alwi featured in one of the chapters of Terug uit Djokja. F.J. Goedhart to R. Alwi, December 30, 1946. Ibid. In 1946, Alwi was correspondent of $R a^{\prime} j a t$ Kedaulatan. A year later, he worked for Antara and Merdeka. Goedhart asked the editor-in-chief of $H e t$ Parool to appoint Alwi as Indonesian correspondent. This request was not honored. F. J. Goedhart to G. J. van Heuven Goedhart, December 2, 1946. Ibid. In 1948, Alwi moved to Amsterdam where he got a job as a professional translator. He translated into English van Mook's book, Indonesië, Nederland en de wereld (Amsterdam: De Bezige Bij, 1949), among others.

33 Subandrio to F. J. Goedhart, October 17, 1946. ARA II, arch. Goedhart corr. Indonesië.
} 
things she had heard about the Indonesian Republic. ${ }^{34}$ Van Mook recommended that Jonkman, the minister of Overseas Territories, read Goedhart's account of his Indonesian experiences. Trying hard at that time to reach an agreement with the Republic, Van Mook was impressed by Goedhart's announcement that the Republic's government was willing to cooperate with the Netherlands if only it were recognized first. ${ }^{35}$ Others in the colonial society, such as General Spoor, felt, however, that Goedhart was only subverting Dutch authority. ${ }^{36}$ Goedhart himself was rather disappointed about the impact of his report. He wrote to Schermerhorn that, after the publication of Terug uit Djokja, he had received mostly disapproving letters. People simply did not want to believe that the Republic was not in complete chaos. Whoever opposed that view was usually regarded as "a traitor, a fascist or a bolshevik."37 Publication of a report by a Dutch delegation led by P.J. Koets, that, officially invited by the Republic's government, visited Yogyakarta in the third week of September, had an equally small impact on the Dutch mind. Presented to Jonkman a month later, this report generally confirmed Goedhart's views and stated that Sukarno, given his grip on the masses of the Indonesian people, held a strong political position in the Republic. ${ }^{38} \mathrm{But}$, as in the case of Goedhart's book, Koets' report was hardly noticed by the Dutch press. ${ }^{39}$ Perhaps Goedhart's tendency to overestimate the influence of political leadership and the impact of the written word led to his disappointment with the reception of his book's message. Instead of recognizing the slow force of change, he tended to explain his relative ineffectiveness by accusing politicians and press of deliberate sabotage for selfish reasons. ${ }^{40}$

\section{Back in Politics Again}

The Labor Party's Indonesia Congress was scheduled to be held on September 7, 1946. Goedhart felt that he could not miss this opportunity to propagate his own views. The day before the congress convened, he was back in the Netherlands. By that time, the party leadership must already have known that Goedhart would take Schermerhorn's seat in Parliament after the official installation of the Commission General a few days later and, consequently, after its chairman's departure to Indonesia. Goedhart's opinion about Indonesian affairs had to be reckoned with in the future. As a result, he was asked to deliver a short speech about his experiences in the Indonesian Republic.

The congress was led by the party's chairman Koos Vorrink, who was striving hard to reconcile as much as possible the members' differing views. After the opening address, the next speech was by L.N. Palar, an Indonesian and socialist member of Parliament. He fully agreed with the party's Indonesian policy, stressing that, although the party apparently wanted to keep a specific relationship between Indonesia and the Netherlands, such a relationship could only be the outcome of a decision taken by Indonesia in all freedom and by mutual arrangement. With this policy, Palar stated, the party registered disagreement with

\footnotetext{
34 J.S.M. Brouwer-Blom to F. J. Goedhart, June 15, 1947. Ibid.

35 H. J. van Mook to J. A. Jonkman, September 2, 1946. In Van der Wal et al., Officiële bescheiden, 5: 288-89. Cf. Schenkman, De Indonesië-reizen van Goedhart, p. 23.

36 Van der Wal, et al., Officiele bescheiden, 6: 621-22. Cf. Schenkman, De Indonesie-reizen van Goedhart. p. 23.

37 F. J. Goedhart to W. Schermerhorn, October 21, 1946. ARA, arch. Goedhart, corr. Indonesië.

38 Verslag van het bezoek van het gezelschap dr. P.J. Koets aan Republikeinsch gebied op Java, 15-20 September 1946 [Report of the visit of the group of Dr. P.J. Koets to Republican territory on Java, September 15-20, 1946] (The Hague: Staatsuitgeverij, 1946), pp. 1-5.

39 Goedhart to Soedjatmoko, September 30, 1946. ARA II, arch. Goedhart, corr. Indonesië.

40 This evaluation of Goedhart's character is founded on my research about Goedhart's prewar and wartime political and journalistic carreer. De Keizer, Het Parool 1940-1945, chapter 1 and passim.
} 
the more conservative interpretations of Indonesia's future as outlined in Queen Wilhelmina's December 1942 speech, according to which the eventually independent Indonesia would be obliged to assent to an association with the Netherlands in the Kingdom of the Netherlands. ${ }^{41}$

Subsequently Logemann, the former minister of Overseas Territories, presented the party's current standpoint to the congress. He stated that, although the party recognized Indonesia's right to autonomy, the Dutch people preferred to maintain a certain political and socio-economic continuity with the past, to the benefit of both Indonesia and the Netherlands. After the Hoge Veluwe talks, however, the nationalists had grown so suspicious of the Dutch intentions that they no longer "dared" [sic!] to continue their association with the Netherlands. It was, therefore, essential first to restore their confidence. Following this lofty presentation of socialist anticolonialist principles, Logemann quickly reverted to the usual colonial discourse, emphasizing that the Dutch still had a task to fulfill and interests to defend in Indonesia. The chaotic situation in the Indonesian Republic, the problematic existence of the Indonesian Republic next to the so-called Malino territories, the future of the Dutch in Indonesia, and Dutch economic interests all forced them to continue this task. The third part of Logemann's speech was devoted to the problem of whether the Dutch should be allowed to use military force if they failed to perform their task, either through their own fault or through that of the other side. He did not categorically reject the use of force, and only with regard to the federation policy pursued by the Dutch did he guarantee that, "if the Republic (or whatever party) did not want to stay associated with the Kingdom of the Netherlands, no war would be waged by the Dutch." In conclusion, Logemann announced that the party was willing to negotiate with every delegate of the Republic, thereby changing its former line that the Dutch should never negotiate with the "collaborator" Sukarno. This change of view was possibly meant to be a concession to the more radical party members, in order to win their approval for the party's policy of supporting the forthcoming dispatch of Dutch military forces to Indonesia. Logemann stressed that, in addition to furthering the aim of reaching an armistice with the Republic, their task was also to protect the security of the Dutch in Indonesia, as well as that of the Indonesians and the Chinese. ${ }^{42}$

Vorrink allowed Goedhart to take the floor after Logemann. Goedhart's brief and, according to Het Parool, humorous account of his recent positive impressions in the Republic counteracted Logemann's more pessimistic views about the chaotic and dangerous situation on Java and Sumatra, without affecting the party's policy in any way. ${ }^{43} \mathrm{His}$ amendment to the original resolution (prepared by the party's central committee), which stated the willingness of the Netherlands to do its utmost to help construct a modern democratic system in Indonesia in order to implement a socialist welfare program, received hardly any support. ${ }^{44}$ Goedhart, nevertheless, noticed that the delegates found his account astonishing. ${ }^{45}$

\footnotetext{
41 Verslag van het Congres-Indonesië gehouden door de Partij van de Arbeid op 7 september 1946 [Report of the Indonesia Congress of the Dutch Labor Party, September 7, 1946] (Amsterdam 1946), pp. 4-14.

42 lbid., pp. 14-22.

43 Het Parool, September 11, 1946.

44 Verslag van het Congres-Indonesië, pp. 23-24.

45 F. J. Goedhart to Subandrio, November 9, 1946. ARA II, arch. Goedhart, corr. Indonesië.
} 
But, according to Schermerhorn, who attended the congress as well, Goedhart's optimism was not actually shared by the other delegates. 46

On the whole, the delegates got the impression that the Labor Party was pursuing a principled and honest anticolonialist policy, trying to "preserve Indonesia and the Netherlands for each other," but never allowing the use of military force to impose an association with the Netherlands on Indonesia. ${ }^{47}$ Vorrink's closing speech only confirmed the delegates' idea about this crucial problem. He emphasized that under no circumstances would the Labor Party allow the use of military force. If negotiations with the Indonesian nationalists failed, international intervention had to be sought. He warned the delegates that the Labor Party occupied only 29 out of 100 seats in Parliament. Hence it was no use trying to overthrow the government. This would be "unfair" to Indonesia, because the succeeding cabinet would, in that case, be more conservative. Leaving the cabinet seemed justified only if nothing further could be gained for Indonesia. ${ }^{48}$

In the forthcoming months, Goedhart seized every opportunity to give his opinion on Indonesian matters. His voice was heard in Parliament, where he retrieved his seat in September, and in Het Parool. ${ }^{49}$ In the party he could exert influence as a member of its central committee and of its Indonesia Commission, which was to advise the central committee about Dutch colonial affairs in general and about the Indonesian question in particular. He also promoted the Indonesian cause by his membership in the Dutch-Indonesian Society, the "Vereniging Nederland-Indonesië," a pressure group of mainly leftist intellectuals. Founded in late August 1945, this society aimed to bring "a new spirit of equality of rights and a lasting friendship between the peoples of both countries." ${ }^{50}$ Many socialists joined the Dutch-Indonesian Society, but it had no official ties with the Labor Party, whose leadership was quick to recognize that the society would eventually become a platform of opposition to its policy. From the fall of 1946, however, the party had to cope with a group of dissenters within its own ranks. By then some twenty party members formed the so-called Nova Zembla group, ${ }^{51}$ which intended to act as a pressure group in the party, stimulating implemen-

46 C. Smit, ed., Het dagboek zan Schermerhorn. Geheim verslag van prof. dr. ir. W. Schermerhorn als voorzitter der commissie-generaal voor Nederlands-Indië, 20 september 1946 -7 october 1947 (Groningen: Wolters-Noordhoff, 1970), pp. 2-3 [September 20, 1946].

47 The press got this impression as well. In Het Parool, September 11, 1946, the title of an article's paragraph about Logemann's speech was "No military force" [transl.].

48 Verslag van het Congres-Indonesië, pp. 30-31. The resolution that was passed at the end of the congress was: "The Congress, convinced that between the Netherlands and Indonesia no war can be waged and be allowed to be waged, and that the Netherlands is obliged to be helpful in finding a peaceful solution to the problems in Indonesia, believes: that it must strive after an association of state-units in Indonesia, equal in position, the one not subjected to the other in any way, in freedom affiliated as members of a community of nations, that the Netherlands must be willing to negotiate with representatives of the Indonesian Republic, in freedom selected, that as soon as possible an armistice must be concluded on conditions further defined by mutual arrangement, and that the despatch of military forces from the Netherlands must be arranged accordingly, that the unity of Indonesia must be maintained, safeguarding the Indonesians and the non-Indonesian minorities, that appropriate measures must be devised for those who have been expelled from their property and means of existence." Ibid., pp. 31-32.

49 The significance of this outlet for Goedhart is underlined by the fact that the socialist daily Het Vrije Volk had written nothing about the press conference that Goedhart gave after his journey. F. J. Goedhart to K. Voskuil, the editor-in-chief of Het Vrije Volk, September 12, 1946. ARA, arch. Goedhart, corr. Indonesië.

50 Cited in Van Baardewijk, "De PvdA van het koninkrijk 1945-1947," p. 170.

51 The name of the group referred to that of the group's chairman, J. Barents. In the 1590 s the explorer J. Barents, trying to reach India by the northern route, spent one winter on the island Nova Zembla. 
tation of a "new socialism" regarding current problems. ${ }^{52}$ The group soon became a center of opposition to the party's Indonesia policy, with men like Goedhart, De Kadt, and Tas as prominent spokesmen.

On December 17, 1946, Goedhart addressed Parliament. In the preceding month, the Commission General in Batavia had reached an agreement with the Indonesian Republic. Following the signing of an armistice in October 1946, political talks had begun between the two sides. In mid-November an informal agreement was reached, and a first draft of an accord was initialed by the negotiators in the Javanese mountain resort of Linggajati. In December, the Second Chamber of Parliament discussed the draft. Goedhart pointed out in his speech that the now seemingly imminent independence of Indonesia was simply a question of "historical justice." A nation with a population of 9 million people could simply no longer rule over a country of 75 million people. At present, he saw a great change in the balance of power that could be curbed "neither by an appeal to the Dutch constitution, nor with reference to former Dutch achievements in Indonesia, nor by manifestations of anger, unwillingness, and irritation, nor by the use of military force." He praised the Commission General and Van Mook for reaching this agreement, which in his opinion should be carried by vote. ${ }^{53}$

In order to get the accord accepted by a majority in the divided Second Chamber, and thus to retain the Catholic-socialist coalition government, a motion was presented in which approval of the agreement was made dependent on new conditions to which the Indonesian Republic was to assent. When this motion was put to the vote, the socialists, Goedhart included, voted for it. As a result the government was induced to resume its negotiations with the Indonesian Republic, that by that time felt deeply humiliated by the unilateral amendment of the original document by the Dutch.

Goedhart's view of the future was not shared by most of his colleagues in Parliament, nor even by the majority of Labor Party members. In the Congress that convened in May 1947 Goedhart was not reelected to the new party's central committee. ${ }^{54}$ Regarding him as a too valuable a member to be that easily discarded, the party's central committee, however, elected him as its consultative member.

Meanwhile, Goedhart had tried to get in touch with people in Indonesia in order to keep well informed about current affairs there. He started to correspond with all the people he had met during his stay there who were willing to respond to his letters. Soon he was carrying on a lively correspondence with J. de Graaff, the chairman of the Dutch Progressive Group in Batavia, and with Koch, the group's representative in Bandung. There was frequent correspondence with Schermerhorn, now in Batavia as chairman of the Commission General. Subandrio, who had become Secretary General of the Republic's Information Service, and his wife became Goedhart's intimate friends. Only two days after his return to the Netherlands, Goedhart sent his first letter to Subandrio. ${ }^{55}$ In October, however, it turned out

\footnotetext{
52 J. Barents to fellow party members, October 10, 1946. IISG, coll. Barents, 175.

53 Handelingen der Staten-Generaal, 1946-1947, pp. 911-15.

${ }^{54}$ F. J. Goedhart to W. Schermerhorn, May 6, 1947. ARA II, arch. Goedhart, corr. Indonesië.

55 While still in Indonesia, Goedhart agreed to send Subandrio regularly books he asked for. From the start, however, this project failed. Although Goedhart sent some books, he received neither any payment from Subandrio nor any answer to his letters. Eventually it appeared that the whole correspondence had been confiscated by the Dutch authorities in Batavia. The confiscated letters are in ARA II, Algemene Secretarie en de daarbij gedeponeerde archieven 1942-1950, no. 5457. The correspondence with Subandrio had its ups and downs, but was continued until August 1953.
} 
that Subandrio had shown one of Goedhart's letters to Schermerhorn, who, after reading its contents, felt rather alarmed and advised Goedhart to observe more prudence in providing information to the Indonesians. Goedhart, for his part, reprimanded Subandrio for having told others about the contents of his letters. ${ }^{56}$

From 1946 to 1953 through his correspondence with many leading Indonesians, Goedhart managed to create a network of valuable informants that formed the basis of his forthcoming mediating role..$^{57}$

\section{A Fair Deal}

In March 1947 the Linggadjati Agreement was passed by the Parliament of the Indonesian Republic. The armistice provided there, however, was often violated. The Republic was not willing to conform to the subordinate and dependent position assigned to it during the projected interim period of Dutch rule, exercised until the union in which it would participate, became effective in 1949. Nor did it accept the presence of a Dutch-Indonesian military force to maintain law and order in the Republic's territories. On the other hand, the financial difficulties of the Dutch government necessitated their reaching a quick solution to the conflict. Maintaining a considerable military force in Indonesia, while not receiving any revenues from most of the colony, threatened to empty the Dutch treasury. In May, Van Mook tried to overcome the deadlock in the negotiations by asking the Republic to consent to the proposed federalist form of government. It was clear that, if the Republic was not willing to conform, Dutch military action against the Republic to force it to accept the Dutch view of the Linggadjati Agreement could hardly be averted.

The growing bellicose mood in the Netherlands induced Goedhart to appeal to Sjahrir. He wrote him a letter, calling attention to the extremely difficult position of the Labor Party if the negotiations in Batavia were to fail again. A politically weakened Labor Party would be very disadvantageous to the Republic. People like Schermerhorn and Van Mook would be replaced by more conservative politicians, with all the ensuing consequences. ${ }^{58}$ This letter was apparently meant to start a more regular correspondence between Goedhart and Sjahrir at this crucial moment. Just a fortnight after his first letter, Goedhart sent a second one, on June 4, 1947. Subandrio and Setiadjit had asked Goedhart to write again, it said. He proposed that he and Sjahrir have a frequent and "completely confidential" exchange of ideas. He sent further letters to Sjahrir on June 5, 12, and $13 . .^{59}$ In the last one, Goedhart informed Sjahrir that the Labor Party's central committee had decided to send him to Indonesia in order to inform Sjahrir about the present situation of the Dutch-Indonesian negotiations, to enlighten him extensively about the political situation in the Netherlands, and to consult with him about a socialist initiative to end the present impasse. ${ }^{60}$ That same day, phrasing the aim of his mission in somewhat different words, Goedhart announced the news in letters to Van Mook and Schermerhorn as well. ${ }^{61}$

\footnotetext{
56 W. Schermerhorn to F.J. Goedhart, October 11, 1946. ARA II, arch. Goedhart, corr. Indonesië.

57 Cf. Schenkman, De Indonesië-reizen van Goedhart, p. 29.(Letters were sent to and often answered by Sjahrir, Sukarno, Palar (after 1947), Hadji Agus Salim, Anak Agung gde Agung, Darsono, Soedjatmoko, and Darmasetiawan, among others. In 1953, Goedhart's relations with Indonesia had changed so radically that almost all his correspondence with Indonesians had stopped.)

58 F. J. Goedhart to S. Sjahrir, May 21, 1947. ARA II, arch. Goedhart, corr. Indonesië.

59 Ibid.

${ }^{60}$ F. J. Goedhart to S. Sjahrir, June 13, 1947. Ibid.

61 F. J. Goedhart to H. J. van Mook, June 13, 1947; F.J. Goedhart to W. Schermerhorn, June 13, 1947. Ibid.
} 
Sending Goedhart to Indonesia was part of a skillful plan by the party's chairman, Vorrink. On June 11, the party's central committee, the socialist members of Parliament, and the party's Indonesia Commission had met, and discussed the rather evasive answer the Republic had given to Van Mook's question regarding a federal form of government. It was agreed that this reply should not be seen as a provocation to military action. On the next day, it appeared that the Commission General was internally divided about how to react to the Republic's response, some favoring advising the Dutch government for and others against military action. In order to avoid a Labor Party split over this problem at the forthcoming party council on June 14, which would result in the fall of the cabinet, the five Laborites directly responsible for the party's Indonesia policy drew up a draft resolution. The day before the party council's gathering, Vorrink went to see Goedhart, to inform him of the contents of this resolution. In order to win support, Vorrink proposed that Goedhart travel to Indonesia as the party's delegate in an attempt to alert the Republic to the critical situation. If Goedhart was willing to go, he had to be loyal to the party line to be set at the coming party council. Also, he had to keep in close contact with Schermerhorn and Van Mook during his stay in Indonesia. ${ }^{62}$

At the party council, Goedhart, backed by other radical party members, succeeded in canceling the paragraph in the resolution's draft that approved military action if the situation turned out to be "intolerable." After consultation with Drees and at the urgent request of Vorrink he withdrew two other amendments to the resolution. Thereupon the party council unanimously passed the resolution. ${ }^{63}$

Once again Vorrink had succeeded in keeping the party together. By allowing Goedhart to go to Indonesia, he had brought this troublesome party member, whose opposition and that of his political friends Vorrink apparently had feared, to conform to the policy of the party leadership. ${ }^{64}$ The confidential mission of this well-known friend of Indonesia seemed highly opportune to Vorrink, as a manifestation of the Labor Party's goodwill toward the Republic. A few weeks earlier, Vorrink had considered going himself, but, in view of the worsening situation, he decided to stay in Holland. ${ }^{65}$ If Goedhart had any success, this would be highly profitable to the party; if not, no harm would be done. Goedhart was, of course, only a delegate or courier of the party and was in no position at all to influence the outcome of the negotiations in Batavia.

But Goedhart also had his own hidden agenda. Now that he and his political friends had capitalized on their opposition in the last few months and his political influence had

62 J. J. Vorrink to W. Schermerhorn, June 16, 1947. Van der Wal, Officiële bescheiden, 9: 348-53. See also: Verslag van de Partijraad [Report of the Party Councill, June 14, 1947. IISG, Arch. PvdA, PR 1947.

63 Ibid. See also: Verslag van de Partijraad, June 14, 1947. Ibid.

${ }^{64}$ Cf. Schenkman, De Indonesië-reizen van Goedhart, p. 30. In his letter to Schermerhorn (see note 62) Vorrink wrote that his visit was highly appreciated by Goedhart and his political friends and that by this strategy he had avoided the problem that the party council, following the instigation of the party's opposition, would succeed in reversing the party's projected policy.

Hearing about Goedhart's mission to Indonesia in a phone call with Logemann on June 13, 1947, Schermerhom wrote in his diary that the party, by sending Goedhart, would be stronger than without this gesture to the left wing. Smit, Het dagboek van Schermerhorn, p. 617 [June 13, 1947].

65 The idea of going himself to Indonesia was already being considered in April. By that time Vorrink gave three reasons why it would be sensible to go: 1 . The Labor Party itself could show its concern about the situation in Indonesia; 2 . the party could meet party members in Indonesia; 3 . such a visit would give publicity to the party. Party executive's minutes, April 17, 1947 and minutes of the party's central committee, April 21, 1947. IISG, arch. PvdA, 1947. 
grown markedly, he felt he was in the right position to mediate in the Dutch-Indonesian conflict. He too had nothing to lose. If he succeeded in bringing the opponents together, he would serve both the Indonesian cause and his own political position. If not, nothing would have changed.

Vorrink expected Goedhart to do no more than explain the extremely painful position of the Dutch Labor Party to the Indonesian socialists, with the hope of persuading them to make concessions. To that end, Goedhart had to deliver a letter to the Indonesian socialist parties, the Partai Sosialis Indonesia, the Partai Buruh Indonesia, and the "Partai Pemuda Sosialis Indonesia" (i.e, the Indonesian Socialist Youth, the Pesindo, which was not a party, but a semi-military organization formed by the merger of a number of youth groups). In this letter, Vorrink stated that the socialist movement in the Netherlands had always been a strong opponent of colonialism and consequently the Dutch Labor Party sympathized with the Indonesian nationalist movement. However, it could not, "given the Dutch situation," support the current Indonesian view on the procedure for transferring sovereignty to the colony. It was the duty of the Dutch Labor Party to implement the Linggadjati Agreement, which it did not consider an onerous task. On the contrary, the party envisaged it, in Vorrink's grandiose statement, "as a matter of honor to prove in the face of the history of mankind that a peaceful liquidation of colonial relations was possible." Socialism meant justice and wisdom. The Dutch Labor Party promised to defend both and asked its Indonesian counterpart to do the same. 66

If Vorrink had thought that the party's delegate would proceed quietly and diplomatically, he was soon disenchanted by the first accounts of Goedhart's activities in Batavia. In part, the endless misunderstandings and problems rising between them in the forthcoming weeks had their origin in the vague arrangements made before Goedhart's departure. But the main reason was that, while Vorrink certainly had a clear idea of the mission's purpose, Goedhart himself had his own interpretation of Vorrink's intentions, witness his letter to Sjahrir dated June 13, cited above. Moreover, asking for a distinct mandate suited neither Goedhart's character nor his political scheme. Vorrink should have known that Goedhart would never be willing to obey orders from anyone. This had been the cause of the flaming row they had had in 1941, when they were co-editors of the Resistance paper Het Parool. Now that at long last he was presented with the opportunity to mediate in the Dutch-Indonesian conflict, Goedhart certainly did not want his freedom to be limited by any directive. Consequently, Vorrink's master plan seemed doomed to fail.

\section{The Party's Delegate}

On June 22, 1947, Goedhart arrived in Indonesia. That same day, he spoke with Schermerhorn in Batavia. The following day he was received by Sjahrir, the chairman of the PSI, to whom he delivered Vorrink's letter. In the first week of July, he met Sukarno, giving the Republican president some books as a gift. From June 28 on, Goedhart regularly reported his thoughts and actions to Vorrink in written accounts and telegrams. ${ }^{67}$

\footnotetext{
66 "Partij van de Arbeid richt zich tot Indonesische socialisten" [The Dutch Labor Party appeals to the Indonesian socialists]. Vorrink published the main points of the letter of June 17, 1947, in his article in Het Vrije Volk, June 18, 1947. It should be noted that, according to this, Goedhart was sent to carry out a "courier service" for the party. The full text of the letter was published in a leaflet, brought out by the Progressive Group in Batavia, June 22, 1947. ARA II, arch. Goedhart, Indonesië.

67 Goedhart sent ten telegrams and seven written accounts to Vorrink between June 28 and July 18, 1947. ARA II, arch. Goedhart, Indonesië [the originals] and IISG, arch. PvdA, 1947, com. 2, portfolio 25 [mimeographs].
} 
Almost immediately after receiving the first of these reports, Vorrink realized that the party's delegate was showing too much initiative, more than he was prepared to take responsibility for. Clearly, there needed to be a definite agreement reached regarding what Goedhart was supposed to accomplish in Indonesia. Vorrink sent Goedhart a letter instructing him that he had to consider his mission as a political-diplomatic assignment. This meant that only after consultation with Vorrink or Schermerhorn (who was a member of the party's central committee) was Goedhart allowed to give a statement to the press. Any projected publication should go via the general press agencies or should be published exclusively by Het Vrije Volk and Het Parool. Vorrink, however, strongly preferred "internal information, internal discussion and forming of opinion, and internal, very discreet intervention" over any publicity whatever. His letter ended with fatherly advice:

You should listen when I tell you that not everything can be solved with "dynamics". Dynamics can become rashness, destroying on the one hand whatever is created by the other. This is the reason why your public political performance risks failure. ${ }^{68}$

As it turned out, in his talks with the leaders of the PSI, PBI, and Pesindo, according to the Indonesian papers, Goedhart had referred to strictly confidential internal party politics. In the Netherlands, this caused some commotion, which was highly inopportune for the Labor Party. Nor was Goedhart's diplomatic gift of books to Sukarno widely applauded. Goedhart had presented these explicity on behalf of the Labor Party. At home, this was immediately denied by the party. Most of all, Vorrink was annoyed by Goedhart's making use of Het Parool as his exclusive publicity medium. The day after Vorrink received Goedhart's first important telegram, copies of which Vorrink personally gave to the prime minister, the six Laborite ministers, and three other directly concerned party leaders, its text was published in Het Parool. 69

Goedhart's gift of books to Sukarno is a fair example of his specific interpretation of the party's assignment. In order to fulfill his mission loyally and to get the most out of it, he felt it necessary to free himself from the Labor Party's legalistic strategy and frame of mind. In carrying out his "goodwill mission," he wrote to the party, it seemed only wise to offer Sukarno the books on behalf of the party and not as a personal gift. Goedhart cynically reminded his readers that, after all, Sukarno was the president of the Indonesian Republic, which was recognized de facto by the Dutch government and was also the other party in the Linggadjati Agreement. His gesture had to be considered as a demonstration of the party's goodwill, and was indeed regarded as such by the Indonesians, including the Indonesian press. $^{70}$

Goedhart's statement to the Indonesian press ("In the name of the Dutch Labor Party") should be regarded as another manifestation of his attempt to strengthen confidence in the party among both Indonesians and Dutch in Indonesia. The letter was written after he had found that Vorrink's well-written diplomatic letter had been badly received by the Indonesian socialist leaders. ${ }^{71}$ The style and composition of the very outspoken statement were

68 J. J. Vorrink to F.J. Goedhart, July 5, 1947. ARA Il, arch. Goedhart, corr. Indonesië. 69 Ibid.

${ }^{70}$ F. J. Goedhart to "Dear friends and party members," July 16, 1947. Among the books Goedhart gave as a present were those of prominent party members such as M. van der Goes van Naters, J. W. Hofstra, and J. Tinbergen, in addition to his own Terug uit Djokja.

71 Goedhart told Schermerhorn about the meetings of the PSI, PBI, and Pesindo he had attended. Schermerhorn felt that Vorrink's letter, although more impressive than the party's ambivalent resolution of June 14, 1947, had 
typical of Goedhart. His intention was to restore nationalist confidence in the party's willingness to reach a peaceful agreement, while at the same time asking the Indonesians to adjust to the complex situation of the party in accomplishing this. In no way, however, did the letter deviate from the party's line.72

Again, Vorrink was neither pleased by Goedhart's interpretation of his letter nor much amused by the reports of his delegate's accomplishments. The decision to send Goedhart to Indonesia had been hastily made by only a few party leaders, while the party's central committee was not even consulted. As long as everything went well this posed no problems, but members of the party's central committee apparently had protested against the whole secretive procedure of Goedhart's dispatch. This had put the party chairman in a difficult position. Furthermore, Vorrink did not want to expose the party to the criticism of other parties. Already, questions had been raised as to whether the Labor Party was trying to set up a second government in Batavia. ${ }^{73}$ As a result, the party's central committee specifically stated in Het Vrije Volk that Goedhart had given his statement to the Indonesian press on his own initiative. ${ }^{74}$ Ten days before, Goedhart had received a stern letter from Vorrink, written like the earlier one on personal stationery rather than on the party's letterhead, in which Goedhart was forbidden to speak any longer about himself as "the party's representative" and was again asked to avoid if possible any publicity in the press. ${ }^{75}$

While Goedhart's movements in Indonesia turned out to be a liability rather than an asset to the Labor Party in the Netherlands, in Batavia there was also steadily increasing annoyance at his strategy. Initially, Schermerhorn was very satisfied with the delegate's work, having been rather skeptical beforehand about Goedhart's possible success and expecting that Goedhart and the party's opposition would now reach the conclusion that the situation was utterly "hopeless." At that time, Van Mook, too, had appreciated Goedhart's actions. ${ }^{76}$ Yet, gradually Schermerhorn's enthusiasm gave way to deep concern, starting with Goedhart's proud announcement that, as he was being provided lodgings in Batavia by the Republic, he was "Sjahrir's guest" now. An irritated Schermerhorn told him that to state this in public was not only untrue but also highly damaging to the party. ${ }^{77}$

At the end of the first week of July, the atmosphere seemed completely ruined. By that time, Goedhart was deeply disappointed in his lack of effectiveness. He complained to Schermerhorn about obstruction by the Commission General in providing the necessary information to fulfill his task as a "political observer."78 Schermerhorn had entirely lost faith in Goedhart's diplomatic skills. He felt that the party's delegate had only strengthened the resistance in Yogyakarta to the Dutch by stating to journalists that, should a military conflict

come too late. It was not published in the Indonesian press until June 27. Schermerhorn speculated that it was not even known in Yogyakarta by that time. Smit, Het dagboek van Schermerhorn, p. 672 [June 27, 1947].

72 [F. J. Goedhart], "Het standpunt van de Partij van de Arbeid" [July 9, 1947]. ARA II, arch. Goedhart, Indonesië.

73 J. J. Vorrink to F.J. Goedhart, July 9, 1947. Ibid., corr. Indonesië. In the party executive's gathering of July 19, 1947, Vorrink had to defend the decision to send Goedhart to Indonesia. IISG, arch. PvdA, PB, 1947.

74 Het Vrije Volk, July 20, 1947.

75 J. J. Vorrink to F. J. Goedhart, July 9, 1947. ARA II, arch. Goedhart, corr. Indonesië.

76 Smit, Het dagboek van Schermerhorn, p. 668 [June 23, 1947].

77 W. Schermerhorn to J.J. Vorrink, June 26, 1947. Van der Wal, Officiële bescheiden, 9: 473-74; Smit, Het dagboek van Schermerhorn, p. 672 [June 27, 1947]. Goedhart was lodged in one of the Republican government houses, not in Sjahrir's private home.

${ }^{78}$ F. J. Goedhart to W. Schermerhorn, July 7, 1947. ARA II, arch. Goedhart, corr. Indonesië. 
break out, the present Dutch cabinet would have to resign, in view of the overwhelming Dutch domestic opposition to war. Goedhart had argued that, in that event, the cabinet would presumably be replaced by a more conservative one, while at the same time massive strikes would break out. ${ }^{79}$ Hearing this, Van Poll, the representative of the Catholic Party in the Commission General, took Goedhart to task, telling him in a meeting of the Commission General that such behavior by the cabinet's ministers, after having reached a joint decision, would be very cowardly. He reproached Goedhart for being disloyal to the nation by strengthening the resistance to the Dutch in Yogyakarta. Moreover, by suggesting that in the Netherlands the forces of "reaction" had gained victory, he had limited the ability of the Dutch negotiators to profit from a situation where foreign powers had to recognize that even those Dutch who had tried hard to reach an agreement were now convinced of the necessity of a military action. In sum, Goedhart was politically "incompetent." 80 Not only Schermerhorn and Van Poll, but also the military leaders ${ }^{81}$ and the Dutch press in Batavia, were very embarrassed by Goedhart's diplomatic approach. The Nieuwsgier published a rather hostile article by its influential editor-in-chief J.H. Ritman. ${ }^{82}$ Goedhart was extremely angry about this article, mainly perhaps because he was starting to realize, bit by bit, that his ambition to be instrumental in reaching an agreement seemed destined for failure. ${ }^{83}$

Since Goedhart's arrival in Batavia, the negotiations between the Dutch and the Republic had dragged on. As a result of his concessions to the Dutch, Sjahrir had to resign on June 26. Two days later, the American Consul General in Batavia tried to bring the two sides together again. Sukarno showed a willingness to comply with the Dutch proposals. Accordingly, the Dutch gave Ali Budiardjo, the secretary of the Republic's delegation, a letter asking for an immediate clear answer from the Republic. Goedhart had proposed that Schermerhorn accompany Budiardjo to Yogyakarta, but Schermerhorn did not want a socialist Dutchman interfering in the process of decision making in the Republic. ${ }^{84}$ Van Mook considered the Republic's answer, which arrived on July 5, unsatisfactory. Setiadjit and Leimena, both members of the Republic's new government, returned to Yogyakarta to try to obtain a better response.

During most of these crucial first days of July, Goedhart stayed in Yogyakarta. On July 3 , he met Sjarifuddin, the new Republican prime minister. That afternoon he held a press conference, warning the Republic about the adverse effects of its evasive and indistinct answers to Dutch proposals and questions. The next day, he had a "straight talk" with Setiadjit, now vice-prime minister, who was willing to yield to the Dutch as a result of American and English diplomacy. On July 4 and 5, he met Sukarno, who invited him to accompany him on a journey through East and West Java; he saw Sjahrir, Sjarifuddin, and

\footnotetext{
${ }^{79}$ Smit, Het dagboek van Schermerhorm, p. 744 [July 8, 1947].

${ }^{80}$ M.J.M. van Poll to L.J.M. Beel [minister-president], July 7, 1947. Van der Wal, Officielle bescheiden, 9: 605. At first Schermerhorn did not believe that Goedhart had really said this. But after Goedhart's "confession" he was very angry about the affair. Cf. Smit, Het dagboek van Schermerhorn, p. 709 [July 2, 1947) and pp. 744-45 [July 8, 1947].

81 These leaders asked Schermerhorn when Goedhart would finally leave. Smit, Het dagboek van Schermerhorm, p. 745 [July 8,1947 ].

82 Its title was "Hoen kakelt weer" ["The chicken cackled again"]. By "chicken" Ritman referred to Goedhart's pen name, "t thoen," during and after the war.

83 Schermerhorn had noticed that on July 8, two days after his return from Yogyakarta, Goedhart criticized the Republic's politicians for the first time. Smit, Het dagboek van Schermerhom, p. 745 [July 8, 1947].

84 Ibid., p. 700 [June 30, 1947].
} 
Setiadjit again, and spoke with Tanzil, Gani, and other prominent politicians. The next day he returned to Batavia. 85

Meanwhile, Goedhart had duly informed Vorrink about important current events, such as Sjahrir's resignation. ${ }^{86}$ On July 4 , he sent a telegram stating that he had found Sjarifuddin determined to continue Sjahrir's "diplomasi" policy, apparently with the aim of dispelling worried feelings in the Netherlands and in Batavia about the Sjarifuddin government. ${ }^{87}$ Two days later, he declared in a telegram that Sukarno had expressed confidence in the Dutch Labor Party's willingness to reach a peaceful solution. He was, however, disappointed that the party had not yet succeeded in reducing Dutch military forces in Indonesia. Such a gesture could have improved the mutual relationship. On July 10, two days after Setiadjit's return to Batavia, Goedhart advised Vorrink that the Dutch government should immediately appoint a federal government, and at the same time start demobilizing the Dutch forces in Indonesisa. The Republic, he argued, had almost capitulated to the Dutch; now, in return, the Dutch had to show some consideration.

In his telegrams and reports to the Netherlands, Goedhart urged Vorrink to be patient, to fill the vacant post in the Commission General with somebody who really understood the situation, ${ }^{88}$ and to transfer the authority to decide on military action from Van Mook to the Commission General, ${ }^{89}$ a suggestion that was completely unrealistic. By that time Goedhart had, however, become a fervent opponent of Van Mook, whom he considered to belong to the warmongers in Batavia, eager to attack the Republic. While Goedhart had been very close to Van Mook during his earlier stay in Indonesia in 1946, a year later he was initially not even received by the Lieutenant Governor General. ${ }^{90}$

On July 15, a peaceful solution of the Dutch-Indonesian conflict seemed near. The next day, Setiadjit asked for some more time for his government to deliberate about the Dutch proposals. The answer that reached Batavia two days later was unacceptable to the Dutch. In a telegram to The Hague, Van Mook said that there was nothing left for him but military action. On July 18, Setiadjit went back to Yogyakarta to try once more to get the Dutch proposals fully accepted. That day, Goedhart launched a final attempt to avert the impending military action. In a telegram to Vorrink, he urged him to seek the intervention of "an international personality, respected by both parties, from an impartial country like Canada or Switzerland." He emphasized that the present situation was not brought about by the

85 [F. J. Goedhart], "Reports [to Vorrink]," no. 3 and 4. ARA Il, arch. Goedhart, Indonesië; cf. IISG, arch. PvdA, 1947, com. 2, portfolio 25.

${ }^{86}$ This was the telegram that Vorrink personally gave to Beel and others and whose contents were published on the following day in Het Parool.

87 Schermerhorn called this message "hopeful" in his diary. Smit, Het dagboek van Schermerhorn, p. 713 [July 3, 1947].

88 Goedhart suggested appointing instead F. de Boer, who resigned in March 1947, M. de Niet, or A. M. Joekes. The first was a relatively independent Catholic missionary and the second a prominent, originally liberal, socialist member of Parliament, who was considered to be one of the party's Indonesia "experts."

89 Since July 2, Goedhart had known that Van Mook was authorized by the Dutch government to start a military action when he deemed this necessary. Could it be, Goedhart thought, that his mission was after all only a putup job? He posed this question to Vorrink in his report to him, July 2, 1947. ARA II, arch. Goedhart, corr. Indonesië. Cf. Schenkman, De Indonesië-reizen van Goedhart, p. 35.

${ }^{90}$ F. J. Goedhart to W. Schermerhorn, July 7, 1947. ARA II, arch. Goedhart, corr. Indonesië. On the letter had been written [presumably by Van Mook, who had still not received Goedhart at that time]: "He is apparently angry. That is of no use to me, because this hurts the Dutch cause. In that case this mission will fail in its purpose. Let him come and tell you what you think about it." 
malevolence of the Republic, but resulted from the Dutch demand that Dutch military forces be admitted to the territory of the Republic. This was feared by the Republic as an attack on its de facto authority. ${ }^{91}$

Although he had a rather low opinion of Goedhart's opinions and accomplishments, Vorrink nevertheless made some use of his information and advice. To Vice-Prime Minister Drees he mentioned Goedhart's help in persuading the Republic to take a more constructive stance, although he ascribed that change mainly to the Americans and the British..$^{92}$ In a letter to the Laborite ministers, he drew information from Goedhart's reports. The minister of Overseas Territories was permitted to inform the minister of Foreign Affairs about Goedhart's July 14 telegram in which Goedhart had given an account of his interview with Mitcheson, the British Consul General. Mitcheson had shown great disappointment about the stubborn attitude of the Dutch in the face of the British and American initiatives to overcome the deadlock in the negotiations. Apparently, Vorrink did not consider Goedhart's reporting very opportune for the party, and did not send Goedhart's reports and telegrams to the party's central committee and the socialist members of Parliament until July $18 .{ }^{93}$ By then, however, it was too late for Goedhart's points of view to exert any influence. Tragically, his last passionate attempt to avoid military action-urging Vorrink to ask for international intervention-had quite the opposite effect on Vorrink and the party's central committee. They drew the conclusion that even Goedhart could no longer envisage a peaceful solution. International intervention at that moment, and by countries like Canada or Switzerland, was not regarded as politically viable. ${ }^{94}$

Two days later, on July 20,1947, the Dutch military attack-the so-called first Police Action-was launched. That night, Goedhart was arrested by soldiers of the Dutch East Indies Army at the home of his friends in Jalan Bonang, where he was staying. He could not help thinking back to the days of the German occupation. Soon, one of the Dutch officers offered him his apologies and released him. In the morning, Goedhart went through the gardens to Sjahrir's house where he met Gani, Tanzil, and others, being guarded by Captain Westerling. He shook hands with them and professed how terrible and useless this Police Action appeared to him. ${ }^{95}$ That same day, July 21, he wrote Schermerhorn a letter:

Last night, Dutch soldiers have been dispatched by Van Mook [the head of the government of the Dutch East Indies], authorized by the Dutch government in The Hague, of which six ministers are members of the Labor Party. I am strongly convinced that the socialist masses of our people will oppose this colonial war that was declared on behalf of the Labor Party as well. We face a terrible crisis. The incompetence of the socialist leaders, their impotence, their failure to defy the bourgeois reaction, and the fact that some leaders of the party are not real socialists at all vindicate themselves now. Because of the countless faults made by our party, the warmongers could no longer be resisted. As a result, they are now trying to solve the Dutch-Indonesian conflict by force. This is insane and utterly hopeless. This "restricted military action" will only intensify the

91 [F. J. Goedhart], Telegram, July 18, 1947. Ibid., Indonesië.

92 J. J. Vorrink to Drees, June 29, 1947. ARA II, arch. Drees, no. 505, corr.

$93 \mathrm{~J}$. J. Vorrink to party members, July 18,1947 . IISG, arch. PvdA, com. 2, map 25. A pparently, Vorrink had at that time not yet received Goedhart's last three reports, one dated July 12 and two dated July 13 . ARA II, arch. Goedhart, Indonesië.

94 Smit, Het dagboek van Schermerhorn, pp. 807-8 [A ugust 10, 1947], 820 [August 19, 1947]. Cf. Schenkman, De Indonesië-reizen van Goedhart, p. 37.

${ }^{95}$ F. J. Goedhart to R. Alwi, January 1, 1948. ARA II, arch. Goedhart, corr. Indonesië; Het Vrije Volk, July 22, 1947. 
aversion, the distrust and the hatred felt by the Indonesians toward us. They can be beaten by military force, but the willingness of the Republic to cooperate voluntarily with the Netherlands will vanish completely. The Dutch are doing this out of despair: to nobody's benefit. Guerrilla warfare must be anticipated with unforeseen attacks on our army's extended supply lines. Acts of resistance, assaults, and arson against everything Dutch will occur. The party leadership in The Hague can boast of its complicity in this adventure and this bloodbath, being justified by nothing more than by the lack of patience, the presumptuousness, and colonial arrogance of the blanda [Dutch] community in Batavia and its many strongholds in the Netherlands.

I no longer have a task. The Labor Party that sent me to this country on a goodwill mission, in order to strengthen the confidence of the Indonesian people in the Dutch socialist party, this same Labor Party collaborated in this attack on the Republic with tanks and bombers six weeks later. Face to face with my many Indonesian friends I feel deeply embarrassed. I am going back to Holland as soon as possible to induce the mass of our party to revolt against the failed party leadership. ${ }^{96}$

This emotional letter came from a man who had just seen the dissipation of his struggle to mediate successfully in the Dutch-Indonesian conflict that had dominated the Dutch political agenda for the preceding two years. The letter reveals the author's typical hyperbolic style of writing. ${ }^{97}$ Although the letter was addressed to Schermerhorn, Goedhart did not keep its contents strictly confidential. A copy was also sent to his political friends Jacques de Kadt and Sal Tas. ${ }^{98}$ He returned to the Netherlands as quickly as possible. On July 25 he was back in the country.

\section{The Aftermath}

After the Police Action, the Labor Party held an extraordinary congress on August 15 and 16 in order to let the party's rank and file cool down. The view of the party's opposition on the matter was presented by their spokesman, De Kadt. Again, out of fear of a split in the party, the congress members, although not explicitly approving the party line, did not deliver a statement of disapproval either. ${ }^{99}$ Despite the debate that arose between the opposition and the party leadership over the right interpretation of the congress' resolution, it was clear that most of the opposition was prepared to follow the party leadership. By keeping the Labor Party in the government, it was hoped that a further escalation of the conflict could be prevented and a solution found along the lines of the Linggadjati Agreement. Only a few members who opposed the party's line felt that the Labor Party's support of the Police Action should have resulted in their resigning from the party.

Goedhart, on the contrary, considered that remaining a member of the party was evidence of "political realism," because there was only one socialist party in the Netherlands. He did not want to be sidetracked, but preferred to win the party over to his stand, inducing the party leadership to a more radical Indonesia policy and a tougher line toward its

\footnotetext{
96 F. J. Goedhart to W. Schermerhorn, July 21, 1947. Ibid.

97 Exceedingly striking is the analogy in composition and style between this letter and the first Newsletter that Goedhart published in July 1940. De Keizer, Het Parool 1940-1945, pp. 16, 43-44.

98 Goedhart had written their names on his own copy of the letter.

${ }^{99}$ Verslag van het Partijbestuur van de Partij van de Arbeid over de jaren 1947 en 1948 [Report of the party executive of the Dutch Labor Party 1947-1948] (Amsterdam, 1948), 196-197.
} 
Roman Catholic coalition partner. ${ }^{100} \mathrm{He}$ did not consider himself co-responsible for the military action, probably agreeing with De Kadt, who wrote in September 1947 that he,

although co-responsible for the viewpoint of the party council and, consequently, for the policy of the party and the Dutch government as well, delegated this responsibility for a policy that he had always withstood and of whose consequences he has always warned (though never able to exert any influence on the party leadership nor on the implementation of its policy) without delay to the leaders, who have power and must be held truly responsible. ${ }^{101}$

After the party congress, Goedhart fell seriously ill. He was physically and psychologically exhausted. ${ }^{102} \mathrm{He}$ had reached the moment of truth. Being strongly aware of his very embarrassing position as a powerless member of a party that in the end turned out to be coresponsible for a colonial war, he blamed the personal and political weakness of others. In October 1947, he wrote to De Graaff that the Indonesian cause seemed completely lost because of the Dutch government's lack of understanding. The Dutch Labor Party no longer had any effective power. Its ministers almost embraced the reactionary viewpoints of the Dutch colonialist conservatives. One minister held the opinion that one had to govern at any cost; a second stated that one had to confront the Indonesian Republic in order to safeguard Dutch economic interests; a third did not want to abandon the Dutch East Indies at all; and a fourth appeared less a Labor minister than an "orangist [royalist] liberal." The party's chairman and the leader of the socialists in Parliament were so keen about maintaining the government coalition that they did everything to avoid a crisis. ${ }^{103}$ Compelled to choose between the Dutch and the Indonesian cause in the summer of 1947, the middleman must have realized that he had no alternative but to serve the first of these.

\section{Conclusion}

Goedhart's painful Indonesia experience in the first two years of the Dutch-Indonesian conflict, which culminated in the summer of 1947 in the complete failure of his activities as a middleman, is more than just another striking manifestation of the well-known traumatic ambiguity in the makeup of a go-between. It also pathetically highlights the ambivalence of European socialist anticolonialist ideology. In spite of its sympathy with the nationalist struggle against colonial rule, Dutch social democracy clung to an anticolonialist point of view that permitted the subordination of nationalism in Indonesia to Dutch political and economic interests. Consequently, facing the colonial challenge to postwar Dutch politics and society, socialist politicians could not but take refuge in a highly flexible Eurocentric rhetoric.

This essay has attempted to redress a balance of interpretation. Dutch historiography has always honored as the "conscience" of the party the few Labor Party politicians who strongly opposed the party leadership's Indonesia policy, holding them in high regard because of their outspoken and realistic anticolonial standpoint. To quote its foremost historian J.Th.M. Bank:

100 Goedhart had stated this to Schermerhorn. Ibid., p. 782 [July 25, 1947]; F. J. Goedhart to R. Alwi, January 1, 1948. ARA II, arch. Goedhart, corr. Indonesië.

101 De Kadt, "Rampspoed geboren" [The Disaster has broken out], pp. 300-301. This essay is dated September 6, 1947.

102 M.A.A.W. Goedhart-van Alebeek to J. de Graaff, September 3, 1947. ARA II, arch. Goedhart, corr. Indonesië. ${ }^{103}$ F. J. Goedhart to J. de Graaff, October 25, 1947. Ibid. 
With regard to his views on the decolonization of Indonesia and the (missed) chances of the Netherlands, he [J. de Kadt] was far ahead of his compatriots, and far ahead of most of his fellow party members as well. He was right and he would be proved right. ${ }^{104}$

In the previous pages, a reassessment of this position has been made by analyzing Goedhart's actual political and ideological involvement as a middleman in the Dutch-Indonesian question.

Goedhart's mediation displayed a calculated policy, if not a pattern in a middleman's perceptions and behavior. After having fulfilled the first task of the go-between by crossing the border (his visit to Yogyakarta in 1946), he continued relentlessly trying to enhance the mutual understanding between the partners in conflict, to sweeten their bitterness and soften their hatred toward each other, and to persuade them to take a less intransigent position in the negotiations, by translating, excusing, and explaining in Indonesia the exigencies of the domestic policy of the Netherlands, and vice versa.

Definite elements in Goedhart's character and political past stimulated him to play the middleman's role. Preeminently a political activist and an individualist, he was too impatient to go along with the necessities of parliamentary decision making. Although a convinced democrat, he loathed the slow and bureaucratic procedures of Parliament, which, in his opinion, obstructed government's ability to rule efficiently. Rejecting legalism and caution, he embraced dynamic political strategies, nonconformism, and the use of imagination in guiding political processes. His experiences as a Communist and, not least, a brave resistance worker had made him suspicious of all authority and stimulated this creative political approach.

Goedhart's mediation was defined by his specific ideological position in the Labor Party. He belonged to a group of former independent socialists and other democratic party members, who, though not socialists by origin, welcomed the new Labor Party's intended nondogmatic, progressive, and democratic political line, which enabled it to participate in government. Regarding the Dutch-Indonesian conflict as a barrier to the renewal of Dutch politics and society, these people strongly advocated a quick solution.

The interpretation of the Indonesian revolution as a "just war," analogous to the Dutch struggle for independence in the sixteenth century and also during the German occupation, was at the root of the group's decolonization policy, which was based on an amalgam of common sense arguments and political pragmatism. Time and again, Goedhart brought to the fore the idea that socialists should support the nationalist struggle in Indonesia because of "historical justice," or claimed that a nation of 75 million people could not be ruled by one of 9 million people; he referred to the economic advantages the Dutch would enjoy after loosening their bonds with Indonesia, and pointed out the weak political situation of the Netherlands vis-à-vis the Anglo-American alliance that strongly favored an agreement with the Indonesian Republic. This pragmatic anticolonial rhetoric was highly functional. It maintained socialist anticolonialism on the one hand while demonstrating the Labor Party's goodwill to Indonesian nationalists on the other, but at the same time it permitted the party to follow a political course that secured its present position.

The political career of Goedhart and other "pragmatic" anticolonialists pointedly illustrates that their arguments in favor of Indonesia's independence did not stop them from always following the party line in the end. Both the amendments to the Linggadjati Agree-

104 J.Th.M. Bank in the epilogue to the republication in 1989 of J. de Kadt's De Indonesische tragedie, p. 186. Bank refers in this quotation to the subtitle of De Kadt's book, The tragedy of missed chances. 
ment and Van Mook's federalism were accepted by them, just like, finally, the launching of the first Police Action, because these moves did not essentially affect their pragmatic anticolonial discourse nor interfere with the party's prime objectives. The "pragmatists" masked their ultimate loyalty to the party by pointing to the leadership as responsible for measures they themselves, although under protest, sanctioned, and by denouncing Dutch decolonization politics on the whole as consisting of "missed chances" by both the Labor Party and the Catholic Party.

Although aware of the fact that Indonesia was experiencing a national and social revolution, Goedhart, De Kadt, and other "pragmatists" never really understood the weight of what was happening in Indonesia nor the political realities with which the Indonesian politicians had to cope. Like most Dutch socialists, they were inclined to overestimate the political strength of the socialists in Yogyakarta in this period, underestimating other politically operative strains. As long as a reasonable, Western-oriented, and moderate socialist like Sjahrir led the government, the striving of the nationalists was seen as deserving all help. In that case, the Labor Party had to stimulate mutual trust and understanding, which, combined with the goodwill and generosity of some key figures in the political process on both sides, were considered to be major factors in solving the conflict. In this policy the undisputable right of Indonesia to the status of a self-governing country was emphasized. After the launching of the first Police Action in the summer of 1947, this position was no longer credible. By that time, however, the "pragmatists" were embracing a "Cold War" notion of decolonization, which saw Indonesia's eventual full sovereignty as conditional on its professed and exclusive economic and political alliance with the countries of the Western democratic world. This new concept generated a new rhetoric that enabled them to accept the party leadership's expedient Indonesia policy without essentially changing their former anticolonialist position. 